Check for updates

Cite this: RSC Adv., 2018, 8, 29670

\title{
Formation of $\mathrm{Mn}-\mathrm{Cr}$ mixed oxide nanosheets with enhanced lithium storage properties $\dagger$
}

\author{
Liewu Li, (D) Liping Wang, ab Mingyu Zhang ${ }^{\star a}$ and Qizhong Huang ${ }^{a}$ \\ Novel carbon-free $\mathrm{Mn}_{2} \mathrm{O}_{3} / \mathrm{MnCr}_{2} \mathrm{O}_{4}$ hybrid nanosheets are synthesized through thermal decomposition of \\ the facilely co-precipitated $\mathrm{Mn}-\mathrm{Cr}$ binary hydroxide and a carbonate hybrid precursor. As an anode for \\ lithium-ion batteries, the $\mathrm{Mn}_{2} \mathrm{O}_{3} / \mathrm{MnCr}_{2} \mathrm{O}_{4}$ electrode delivers a wonderful electrochemical performance, \\ i.e., an enhanced stability of $913 \mathrm{~mA} \mathrm{~h} \mathrm{~g} \mathrm{~m}^{-1}$ at a current density of $1 \mathrm{~A} \mathrm{~g}^{-1}$ after 300 cycles, and an \\ excellent rate performance. The excellent electrochemical performance of the $\mathrm{Mn}_{2} \mathrm{O}_{3} / \mathrm{MnCr}_{2} \mathrm{O}_{4}$ \\ electrode can be ascribed to the interconnected nanosheets and porous structure, as well as the \\ possible synergistic effects between $\mathrm{Mn}$ and $\mathrm{Cr}$ mixed oxides.
}

Received 7th June 2018

Accepted 20th July 2018

DOI: $10.1039 / c 8 r a 04868 a$

rsc.li/rsc-advances

buffer volume change, as well as accommodate structural stress generated during cycling. ${ }^{13-28}$

So far many relevant studies have been reported about

With the economic growth and the demands of climate protection, rechargeable lithium-ion batteries (LIBs) have established themselves in dominant roles for portable electronic devices and electric vehicles. ${ }^{1-4}$ However, conventional anode materials of graphite cannot meet the urgent demands for heavy-duty applications due to the low theoretical capacity, poor rate performance and serious safety issues owing to the formation of lithium dendrites on its surface even at a charging current density of $4 \mathrm{~mA} \mathrm{~cm}{ }^{-2}{ }^{5,6}$ In order to meet the requirements for large-scale energy storage, transition metal oxides (TMOs, $\mathrm{M}=\mathrm{Mn}, \mathrm{Fe}, \mathrm{Co}, \mathrm{Ni}, \mathrm{Cu}, \mathrm{Cr}$, etc.), especially those of mixed valence oxides involving different metal elements, have been extensively exploited as very promising alternatives to graphite as anode materials (TMOs have about twice the capacity of carbon per unit mass, and three times its density, therefore, TMOs have about 6 times the capacity of carbon per unit volume).$^{7-10}$ Although TMO anode materials exhibit high theoretical capacity for LIBs, they are seriously hampered by the gigantic volume changes and dramatic mechanical stress upon lithiation and delithiation, resulting in cracking and pulverization and loss of electrical contact between particles and the current collector, thereby leading to rapid capacity fading. ${ }^{11,12}$ In order to solve these issues, introducing a second phase element or multiphase materials has proved to be an effective way for the transition metal to increase the electronic conductivity, improve $\mathrm{Li}^{+}$diffusivity, separate the multiphase phases from each other,

${ }^{a}$ State Key Laboratory of Powder Metallurgy, Central South University, Changsha, 410083, China.E-mail: zhangmingyu@csu.edu.cn

${ }^{b}$ Department of Biological and Environmental Engineering, Changsha University, Changsha, 410022, China

$\dagger$ Electronic supplementary information (ESI) available. See DOI: multiphase TMOs nanocomposite anodes with excellent electrochemical performance. ${ }^{29-33}$ Liu et al. showed that by substituting a small amount of $\mathrm{Cu}$ into a $\mathrm{Co}_{3} \mathrm{O}_{4}$ lattice uniformly, the resulting composite electrode material $\left(\mathrm{Cu}_{3 / 7} \mathrm{Co}_{18 / 7} \mathrm{O}_{4}\right)$ can endure large volume change caused by lithiation/delithiation cycles, thereby maintaining high capacity and cycling stability. ${ }^{34}$ Lin et al. found that $\mathrm{Cr}_{2} \mathrm{O}_{3} @ \mathrm{Ag}_{2} \mathrm{O}$ composite showed much higher specific capacity and better cycling stability than those of bare $\mathrm{Cr}_{2} \mathrm{O}_{3}$ as anode material for LIBs. ${ }^{35}$ Zhou et al. fabricated $\mathrm{CoMn}_{2} \mathrm{O}_{4} @ \mathrm{TiO}_{2}$ submicrospheres for advanced LIBs, after 500 cycles at a current density of $1 \mathrm{Ag}^{-1}$, the $\mathrm{CoMn}_{2} \mathrm{O}_{4} @ \mathrm{TiO}_{2}$ spheres possessed a high reversible capacity of $940 \mathrm{~mA} \mathrm{~h} \mathrm{~g}{ }^{-1} \cdot{ }^{36}$ Despite these achievements in research of multiphase TMOs nanocomposite anodes, the preparation methods are laborious and the cost is not suitable for mass production. Thus, excellent rate capability, outstanding stability and affordable TMOs ande materials produced by scalable synthesis approach should be developed urgently. ${ }^{4}$

Among the TMOs, manganese oxides $\left(\mathrm{MnO}_{x}\right)$ have proved to be attractive choices because of their high theoretical capacity, low potential, high abundance and environmental benignity. ${ }^{12,37-43} \mathrm{Cr}_{2} \mathrm{O}_{3}$ also has been considered as a promising anode material for its high theoretical capacity of $1058 \mathrm{~mA} \mathrm{~h} \mathrm{~g}^{-1}$ and relatively low lithium insertion potential among metal oxides and low-cost. ${ }^{\mathbf{1 1 , 4 4 - 4 7}} \mathrm{MnCr}_{2} \mathrm{O}_{4}$ is an important member of the spinel family and has the normal spinel structure (space group $F d \overline{3} m) .{ }^{48,49}$ The $\mathrm{MnCr}_{2} \mathrm{O}_{4}$ spinel has been widely investigated due to its excellent magnetic and electric properties. ${ }^{50}$ However, to the best of our knowledge, $\mathrm{MnCr}_{2} \mathrm{O}_{4}$ has not been reported as the anode material for LIBs. Thus, the development of a facile method to synthesize nanostructure $\mathrm{MnCr}_{2} \mathrm{O}_{4}$ and its 
composites and elucidation of their electrochemical reaction mechanism for LIBs is of great importance and necessity.

Herein, we report as first time a co-precipitation method for large-scalable fabrication of the $\mathrm{Mn}_{2} \mathrm{O}_{3} / \mathrm{MnCr}_{2} \mathrm{O}_{4}$ hybrid nanosheets based on the recent investigations. The facile synthesis approach has the features of scalable capability, environmentally friendly and low cost. As an anode for LIBs, the $\mathrm{Mn}_{2} \mathrm{O}_{3}$ l $\mathrm{MnCr}_{2} \mathrm{O}_{4}$ electrode delivers an excellent rate performance and an enhanced reversible capacity of $913 \mathrm{~mA} \mathrm{~h} \mathrm{~g}^{-1}$ at a current density of $1 \mathrm{~A} \mathrm{~g}^{-1}$ after 300 cycles. Those outstanding electrochemical performances can be ascribed to the unique boundaries between $\mathrm{MnCr}_{2} \mathrm{O}_{4}$ and $\mathrm{Mn}_{2} \mathrm{O}_{3}$, which can promote $\mathrm{Li}^{+}$ diffusion through the electrode. Furthermore, the structure of interconnected nanosheets and pores can improve electron conductivity in the continuous paths and ensure the electrode full contact with the electrolyte to possess abundant masstransportation channels, moreover, accommodate a large volume change during charge and discharge processes. Improved rate capacity and cycling stability open the door to design of high-performance LIBs anodes.

\section{Experimental section}

\section{Preparation of the $\mathrm{Mn}_{2} \mathrm{O}_{3} / \mathbf{M n C r}_{2} \mathrm{O}_{4}$ hybrid nanosheets}

First, $\mathrm{MnCl}_{2} \cdot 4 \mathrm{H}_{2} \mathrm{O}(40 \mathrm{mmol})$ and $\mathrm{CrCl}_{3} \cdot 6 \mathrm{H}_{2} \mathrm{O}(20 \mathrm{mmol})$ were dissolved in $100 \mathrm{~mL}$ of deionized water (solution 1), $\mathrm{NaOH}(140$ $\mathrm{mmol})$ and $\mathrm{Na}_{2} \mathrm{CO}_{3}(56 \mathrm{mmol})$ were also dissolved in $100 \mathrm{~mL}$ of deionized water (solution 2). Then solution 2 was dropwise added into solution 1, stirring at the same time. The obtained suspension was maintained at $80^{\circ} \mathrm{C}$ for $48 \mathrm{~h}$ in an oven with sufficient ageing. Next, the precipitate was washed by centrifugal washing and dried at $80{ }^{\circ} \mathrm{C}$ for $12 \mathrm{~h}$. Finally, the as-dried precursor was heated in air at $5{ }^{\circ} \mathrm{C} \mathrm{min}^{-1}$ up to $800{ }^{\circ} \mathrm{C}$, kept at this temperature for $2 \mathrm{~h}$, and cooled naturally to room temperature. Grounded by agate mortar to obtain very fine composite powder $\left(\approx 100\right.$ mesh), the $\mathrm{Mn}_{2} \mathrm{O}_{3} / \mathrm{MnCr}_{2} \mathrm{O}_{4}$ hybrid nanosheets was synthesized. The same procedures were applied to synthesize the $\mathrm{Mn}_{2} \mathrm{O}_{3}$ and $\mathrm{Cr}_{2} \mathrm{O}_{3}$ nanomaterials.

\section{Materials characterization}

The morphology and crystal structure of the samples were characterized by scanning electron microscopy (SEM, FEI Nova Nano SEM230), energy dispersive X-ray spectroscopy (EDX, FEI Nova Nano SEM230), transmission electron microscopy (TEM, JEOL JEM-2010), and X-ray diffraction (XRD, Rigaku Dmax/2550 $\mathrm{VB}+18 \mathrm{~kW}$ ). The surface chemical composition of the samples was identified by X-ray photoelectron spectroscopy (XPS) using a multifunctional imaging electron spectrometer (Thermo ESCALAB 250XI) with monochromatic Al $\mathrm{K} \alpha$ radiation. The specific surface areas and pore size distribution of the samples were evaluated from nitrogen adsorption-desorption isotherms using a Quadrasorb SI surface characterization analyzer.

\section{Electrochemical testing}

The electrodes were prepared by mixing $70 \mathrm{wt} \%$ active material, $20 \mathrm{wt} \%$ acetylene carbon black and $10 \mathrm{wt} \%$ polyvinylidene fluoride. Then dissolved the mixture in $N$-methyl-2pyrrolidinone to form slurry. The obtained slurry was coated on copper foil, then dried at $80^{\circ} \mathrm{C}$ for $12 \mathrm{~h}$ under vacuum. Coin cells (CR2032) were fabricated using lithium metal as the counter electrode, Celgard 2400 as the separator, and $\operatorname{LiPF}_{6}(1$ $\mathrm{M})$ in ethylene carbonate (EC) and dimethyl carbonate (DMC) with a $1: 1$ volume ratio as the electrolyte. The assembly of the cell was conducted in an Ar-filled glove box with oxygen and moisture contents less than $1 \mathrm{ppm}$. All measurements were carried out at $25{ }^{\circ} \mathrm{C}$. CV measurements were conducted at $0.1 \mathrm{mV} \mathrm{s}^{-1}$ within the range of $0.01-3.0 \mathrm{~V}\left(\mathrm{vs} . \mathrm{Li} / \mathrm{Li}^{+}\right.$) on a CHI660E electrochemical workstation. Cycle life and rate capability of the cells were tested within a voltage window of $0.01-3.0 \mathrm{~V}$ (vs. Li/ $\mathrm{Li}^{+}$) by using a battery testing system (LAND CT2001A, China) at current densities ranging from 0.1 to $3 \mathrm{~A} \mathrm{~g}^{-1}$. EIS experiments were carried out using a CHI660E electrochemical workstation in the frequency range of $100 \mathrm{kHz}$ to $0.01 \mathrm{~Hz}$.

\section{Results and discussion}

The $\mathrm{Mn}_{2} \mathrm{O}_{3} / \mathrm{MnCr}_{2} \mathrm{O}_{4}$ hybrid nanosheets was prepared by a facile three-step process involving coprecipitation, lavation and calcination (Fig. 1). First, $\mathrm{MnCl}_{2}$ and $\mathrm{CrCl}_{3}$ were dissolved in deionized water to form a transparent solution containing $\mathrm{Mn}^{2+}$ and $\mathrm{Cr}^{3+}$. Similarly, $\mathrm{NaOH}$ and $\mathrm{Na}_{2} \mathrm{CO}_{3}$ were dissolved in deionized water to form a mixing transparent solution containing $\mathrm{OH}^{-}$and $\mathrm{CO}_{3}{ }^{2-}$. Then, the latter solution was dropwise added into the former solution, stirring at the same time to form a uniform suspension contained $\mathrm{Mn}(\mathrm{OH})_{2}, \mathrm{Cr}(\mathrm{OH})_{3}$, $\mathrm{MnCO}_{3}$ and $\mathrm{Cr}_{2}\left(\mathrm{CO}_{3}\right)_{3}$. Through post-thermal calcination, the $\mathrm{Mn}_{2} \mathrm{O}_{3} / \mathrm{MnCr}_{2} \mathrm{O}_{4}$ hybrid nanosheets was obtained. It worth noting that $\mathrm{Mn}-\mathrm{Cr}$ binary hydroxides and carbonates hybrid precursor can be uniformly formed efficiently by the facile coprecipitated method. Furthermore, the porous structures were well formed due to the release of $\mathrm{CO}_{2}$ gas during thermal decomposition of the Mn-Cr binary carbonates. ${ }^{42}$ The details of material synthesis and characterization methods are presented in the experimental section.

From the scanning electron microscopy (SEM) images of the $\mathrm{Mn}_{2} \mathrm{O}_{3} / \mathrm{MnCr}_{2} \mathrm{O}_{4}$ hybrid nanosheets observed in Fig. 2a and b, there are many nanosheets structures and it interconnected with each other. The interconnected nanosheets structures can not only supply enough space to buffer volume change and accommodate structural stress generated during cycling, but

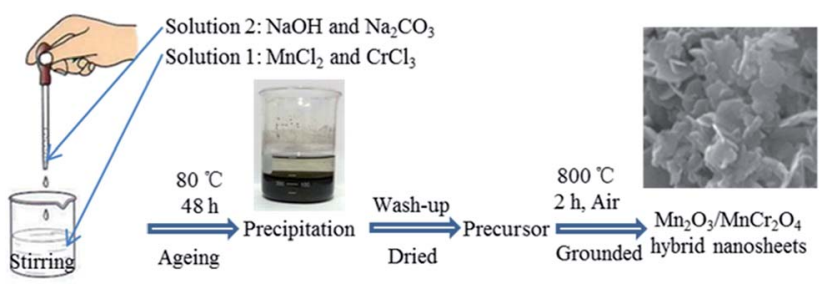

Fig. 1 Schematic illustration of the preparation process of the $\mathrm{Mn}_{2} \mathrm{O}_{3}$ / $\mathrm{MnCr}_{2} \mathrm{O}_{4}$ hybrid nanosheets. 

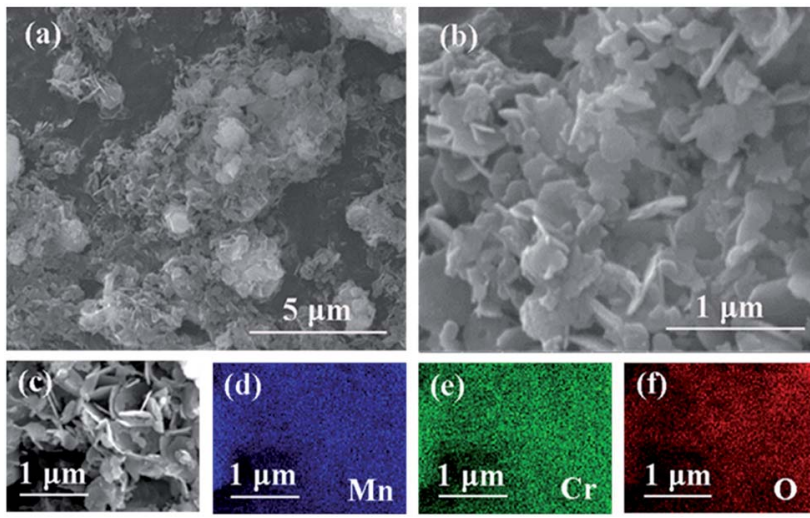

Fig. 2 (a) SEM image of the $\mathrm{Mn}_{2} \mathrm{O}_{3} / \mathrm{MnCr}_{2} \mathrm{O}_{4}$ hybrid nanosheets; (b) high magnification image of (a); (c)-(f) SEM image and $\mathrm{Mn}, \mathrm{Cr}$ and $\mathrm{O}$ elemental mapping of the $\mathrm{Mn}_{2} \mathrm{O}_{3} / \mathrm{MnCr}_{2} \mathrm{O}_{4}$ hybrid nanosheets.

also shorten electronic and ionic transport length. ${ }^{10,39}$ The energy dispersive X-ray spectroscopy (EDX) in Fig. 2c-f reveals the existence of $\mathrm{Mn}, \mathrm{Cr}$ and $\mathrm{O}$ verifying the ingredients of the $\mathrm{Mn}_{2} \mathrm{O}_{3} / \mathrm{MnCr}_{2} \mathrm{O}_{4}$ hybrid nanosheets, and it can be seen that $\mathrm{Mn}$, $\mathrm{Cr}$ and $\mathrm{O}$ are homogeneously distributed in the entire nanosheets. SEM images of the $\mathrm{Mn}_{2} \mathrm{O}_{3}$ and $\mathrm{Cr}_{2} \mathrm{O}_{3}$ nanomaterials are shown in Fig. S1 and S2 (ESI). $\dagger$ The atomic contents of Mn and $\mathrm{Cr}$ elements in the $\mathrm{Mn}_{2} \mathrm{O}_{3} / \mathrm{MnCr}_{2} \mathrm{O}_{4}$ hybrid nanosheets composite were about $43.26 \%$ and $20.17 \%$, respectively, which are determined by the EDX (ESI, Fig. S3 $\uparrow$ ). The results are in good agreement with the initial ratio of manganese chloride and chromic chloride. Therefore, the ratio of $\mathrm{Mn}_{2} \mathrm{O}_{3}$ and $\mathrm{MnCr}_{2} \mathrm{O}_{4}$ in the hybrid nanosheets composite is $\sim 3: 2$.
The typical XRD pattern of the as-prepared $\mathrm{Mn}_{2} \mathrm{O}_{3} / \mathrm{MnCr}_{2} \mathrm{O}_{4}$ hybrid nanosheets is present in Fig. $3 \mathrm{a}$. Three sharp and intense peaks at around $33.0^{\circ}, 38.2^{\circ}$ and $55.2^{\circ}$ are well indexed to the (222), (400) and (440) planes of the cubic $\mathrm{Mn}_{2} \mathrm{O}_{3}$ phase (JCPDS card no. 41-1442), respectively. Another three sharp and intense peaks at around $30.0^{\circ}, 35.3^{\circ}$ and $61.2^{\circ}$ are well indexed to the (220), (311) and (440) planes of the cubic $\mathrm{MnCr}_{2} \mathrm{O}_{4}$ phase (JCPDS card no. 54-0876). The XRD patterns of the $\mathrm{Mn}_{2} \mathrm{O}_{3}$ and $\mathrm{Cr}_{2} \mathrm{O}_{3}$ nanomaterials show in Fig. S4 (ESI). $\dagger$ X-ray photoelectron spectroscopy (XPS) was implemented to investigate the elemental composition, chemical states. Feature peaks in the survey spectra corresponding to $\mathrm{Mn} 2 \mathrm{p}, \mathrm{Cr} 2 \mathrm{p}$ and $\mathrm{O} 1 \mathrm{~s}$ (Fig. 3b). Corresponding to previous literature, the peaks at $653.2 \mathrm{eV}$ and $641.5 \mathrm{eV}$ in Fig. S5a (ESI) $\dagger$ are ascribed to Mn $2 \mathrm{p}_{1 / 2}$ and $\mathrm{Mn} 2 \mathrm{p}_{3 / 2}$, and the bonding energies at the Mn $2 \mathrm{p}_{1 / 2}$ and $\mathrm{Mn} 2 \mathrm{p}_{3 / 2}$ peaks agree well with that of reported for $\mathrm{Mn}_{2} \mathrm{O}_{3}{ }^{43}$ The Mn 2p XPS spectrum exhibited three characteristic peaks at $640.4 \mathrm{eV}$, $641.8 \mathrm{eV}$ and $643.9 \mathrm{eV}$, corresponding to spin-orbit peaks of manganese with mixed valence states of $+2,+4$ and +3 , respectively. ${ }^{51}$ Similarly, in the Cr $2 p$ XPS spectra, the high-resolution spectra of Cr 2p in Fig. S5b (ESI) $\dagger$ shows two distinct peaks at $586.1 \mathrm{eV}$ and $576.7 \mathrm{eV}$, which are respectively ascribed to $\mathrm{Cr}$ $2 \mathrm{p}_{1 / 2}$ and $\mathrm{Cr} 2 \mathrm{p}_{3 / 2}$ levels, respectively. ${ }^{52}$ The peak fitted at $575.7 \mathrm{eV}, 576.8 \mathrm{eV}$ and $578.6 \mathrm{eV}$ mainly belong to $\mathrm{Cr}^{2+} 2 \mathrm{p}_{3 / 2}, \mathrm{Cr}^{4+}$ $2 \mathrm{p}_{3 / 2}$ and $\mathrm{Cr}^{3+} 2 \mathrm{p}_{3 / 2}$ respectively. Consequently, both mixed valence states of $+2,+4$ and +3 coexisted for manganese and chromium in the as-prepared composites. Brunauer-EmmettTeller (BET) measurement was carried out to evaluate the specific surface area and pore size distribution of the $\mathrm{Mn}_{2} \mathrm{O}_{3} /$ $\mathrm{MnCr}_{2} \mathrm{O}_{4}$ hybrid nanosheets (Fig. 3c). A typical IV isotherm with (a)

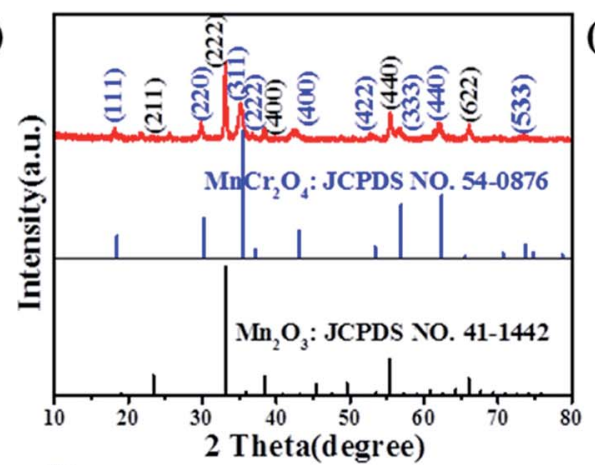

(c)

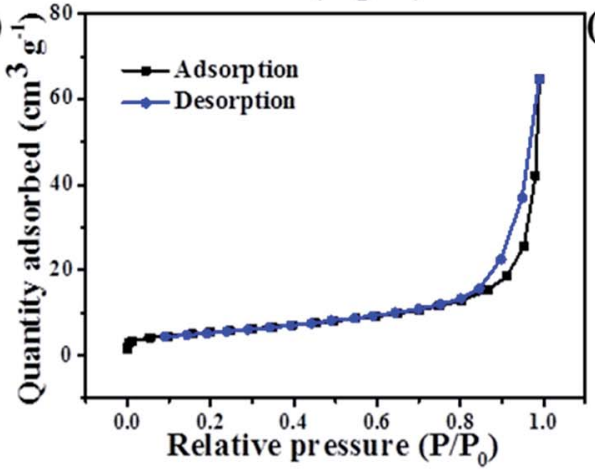

(b)

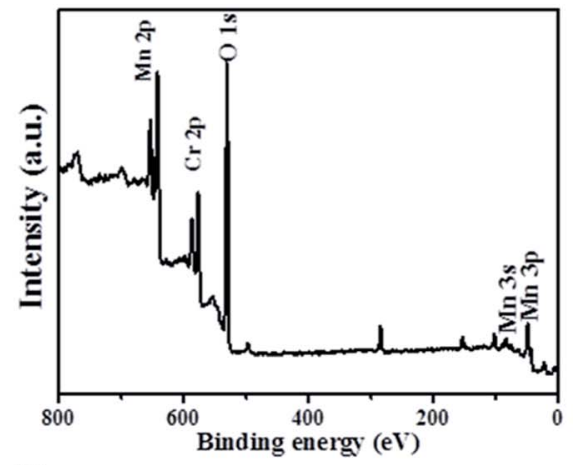

(d)

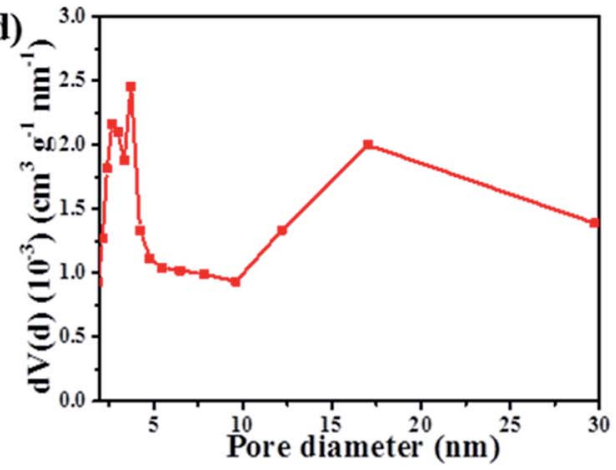

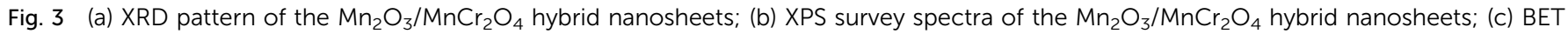
isotherm plots of the $\mathrm{Mn}_{2} \mathrm{O}_{3} / \mathrm{MnCr}_{2} \mathrm{O}_{4}$ hybrid nanosheets; (d) $\mathrm{BJH}$ pore size distribution of the $\mathrm{Mn}_{2} \mathrm{O}_{3} / \mathrm{MnCr}_{2} \mathrm{O}_{4}$ hybrid nanosheets. 

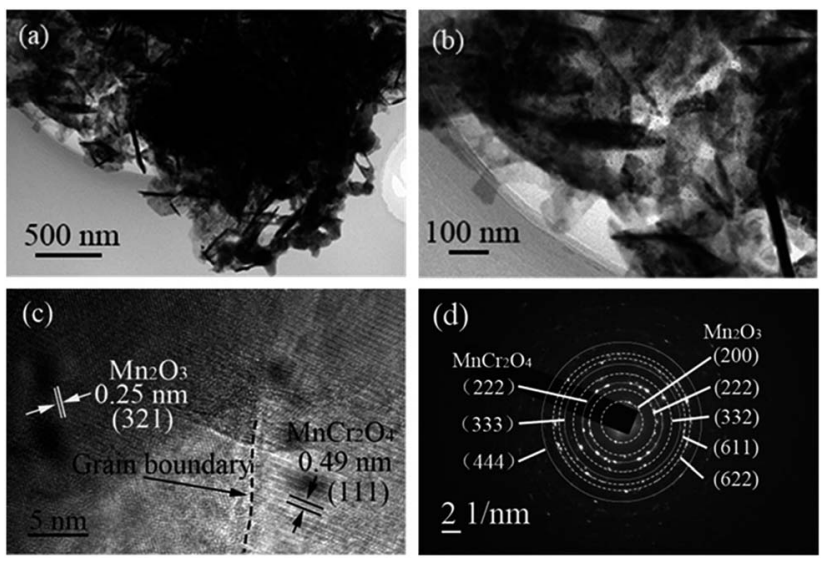

Fig. 4 (a) Bright field TEM image of the $\mathrm{Mn}_{2} \mathrm{O}_{3} / \mathrm{MnCr}_{2} \mathrm{O}_{4}$ hybrid nanosheets; (b) high-resolution TEM image of (a); (c) high-resolution TEM image of (b); (d) SAED patterns of the $\mathrm{Mn}_{2} \mathrm{O}_{3} / \mathrm{MnCr}_{2} \mathrm{O}_{4}$ hybrid nanosheets.

a distinct hysteresis loop in the range of $0.8-1.0 P / P_{\mathrm{o}}$ can be clearly seen, indicating its mesoporous structures. ${ }^{53}$ The BETspecific surface area of the $\mathrm{Mn}_{2} \mathrm{O}_{3} / \mathrm{MnCr}_{2} \mathrm{O}_{4}$ hybrid nanosheets is estimated to be $19.8 \mathrm{~m}^{2} \mathrm{~g}^{-1}$. The pore size distribution calculated from the Barrett-Joyner-Halenda $(\mathrm{BJH})$ method, mesopores distribute from 2.68 to $17.01 \mathrm{~nm}$ in the $\mathrm{Mn}_{2} \mathrm{O}_{3} /$ $\mathrm{MnCr}_{2} \mathrm{O}_{4}$ hybrid nanosheets, and the total pore volume of the nanostructures is calculated to be $0.1 \mathrm{~cm}^{3} \mathrm{~g}^{-1}$ (Fig. 3d). High surface area of the $\mathrm{Mn}_{2} \mathrm{O}_{3} / \mathrm{MnCr}_{2} \mathrm{O}_{4}$ hybrid nanosheets is beneficial to the electrode contact with the electrolyte, moreover, suitable pore size and sufficient pore volume are more favorable for the $\mathrm{Li}^{+}$diffusion and alleviating the volumetric expansion during the lithiation and delithiation processes, leading to enhanced cycle performance..$^{54}$

For more accurate information about the morphology and crystal structure, transmission electron microscopy (TEM) was utilized to characterize the interior structure of the $\mathrm{Mn}_{2} \mathrm{O}_{3}$ / $\mathrm{MnCr}_{2} \mathrm{O}_{4}$ hybrid nanosheets. Fig. 4a clearly illustrates the nanosheets structure, which is in good agreement with the SEM image in Fig. 2b. The nanosheets structure is supposed to accommodate the volume expansion of the $\mathrm{Mn}_{2} \mathrm{O}_{3} / \mathrm{MnCr}_{2} \mathrm{O}_{4}$ during the lithiation process. It also can be clearly observed from the high-resolution TEM image in Fig. $4 \mathrm{~b}$ that each nanosheet of the $\mathrm{Mn}_{2} \mathrm{O}_{3} / \mathrm{MnCr}_{2} \mathrm{O}_{4}$ criss-cross. Fig. $4 \mathrm{c}$ reveals the crystalline nature of $\mathrm{Mn}_{2} \mathrm{O}_{3}$ and $\mathrm{MnCr}_{2} \mathrm{O}_{4}$, the observed $d$ spacing of $0.49 \mathrm{~nm}$ corresponds to the (111) plane of cubic $\mathrm{MnCr}_{2} \mathrm{O}_{4}{ }^{48}$ and the observed $d$-spacing of $0.25 \mathrm{~nm}$ corresponds to the (321) plane of cubic $\mathrm{Mn}_{2} \mathrm{O}_{3}$. An obvious grain boundary can be observed between the $\mathrm{Mn}_{2} \mathrm{O}_{3}$ (321) lattice plane and the $\mathrm{MnCr}_{2} \mathrm{O}_{4}$ (111) lattice plane, indicating that $\mathrm{Mn}_{2} \mathrm{O}_{3}$ and $\mathrm{MnCr}_{2} \mathrm{O}_{4}$ strongly bonded with each other, and it is good for preventing the $\mathrm{Mn}$ or $\mathrm{Cr}$ from aggregation during the lithiation/ delithiation processes. Further more, grain boundaries can introduce fast paths for $\mathrm{Li}^{+}$diffusion. ${ }^{55}$ Additional crystal structure of the $\mathrm{Mn}_{2} \mathrm{O}_{3} / \mathrm{MnCr}_{2} \mathrm{O}_{4}$ hybrid nanosheets was analyzed by the selected area electron diffraction (SAED) patterns (Fig. 4d). The SAED patterns confirm that the nanosheets are $\mathrm{Mn}_{2} \mathrm{O}_{3}$ and $\mathrm{MnCr}_{2} \mathrm{O}_{4}$ hybrid phase, which are in good agreement with the XRD results.

The electrochemical performance of the $\mathrm{Mn}_{2} \mathrm{O}_{3} / \mathrm{MnCr}_{2} \mathrm{O}_{4}$ hybrid nanosheets and other comparison anode materials have been investigated using lithium ion half cells. All of the electrochemical measurements were tested between 0.01 and $3.0 \mathrm{~V}$ (vs. $\mathrm{Li} / \mathrm{Li}^{+}$) at $25^{\circ} \mathrm{C}$.

Fig. 5a displays the typical cyclic voltammetry (CV) curves of the $\mathrm{Mn}_{2} \mathrm{O}_{3} / \mathrm{MnCr}_{2} \mathrm{O}_{4}$ electrode for the initial five cycles at a scan rate of $0.1 \mathrm{mV} \mathrm{s}^{-1}$. In the initial cathodic process, the small peak at about $0.81 \mathrm{~V}$ is resulted from the formation of a solid-electrolyte interface (SEI) film..$^{12}$ Further more, two main lithiation peaks centered at 0.30 and $0.11 \mathrm{~V}$ can be assigned to the conversion reaction of the $\mathrm{Mn}_{2} \mathrm{O}_{3}$ and $\mathrm{MnCr}_{2} \mathrm{O}_{4}$ with lithium. ${ }^{11,12}$ For the second and following cycles, the peaks located at $0.81 \mathrm{~V}$ and $0.11 \mathrm{~V}$ disappeared, and the reduction peak shifted to higher potential of $0.44 \mathrm{~V}$ due to the improved reaction kinetics after the first lithiation. ${ }^{37}$ During the anodic process, the oxidation peak located at $1.3 \mathrm{~V}$ in the reverse sweep is ascribed to the re-oxidation of metallic $\mathrm{Mn} / \mathrm{MnO}, \mathrm{Cr} / \mathrm{Cr}_{2} \mathrm{O}_{3}$ and the decomposition of $\mathrm{Li}_{2} \mathrm{O} .^{11,12}$ The charge-discharge profiles at the current densities of $0.1,0.2,0.5,1,2$ and $3 \mathrm{~A} \mathrm{~g}^{-1}$ for the 1st, 11th, 16th, 21st, 31st and 36th cycles are displayed in Fig. 5b. The potential of the $\mathrm{Mn}_{2} \mathrm{O}_{3} / \mathrm{MnCr}_{2} \mathrm{O}_{4}$ electrode increases/decreases monotonically with obvious potential plateau when charge/discharge at various current density, which is a typical behavior of ion conversion dominated energy storage mechanism. ${ }^{9}$ The distinct plateaus at around $0.5 \mathrm{~V}$ and $1.3 \mathrm{~V}$ in the discharge and charge profiles are in accordance with the CV curves, matching well with the reduction and oxidation of $\mathrm{Mn}^{3+}$ and $\mathrm{Mn}$, respectively. The distinct plateaus at around $0.2 \mathrm{~V}$ and $0.15 \mathrm{~V}$ in the discharge profile can be related to the reduction of $\mathrm{Mn}^{2+}$ to the $\mathrm{Li}_{2} \mathrm{O} / \mathrm{Mn}$ and $\mathrm{Cr}^{3+}$ to the $\mathrm{Li}_{2} \mathrm{O} / \mathrm{Cr}^{56,57}$ The first discharge and charge capacities are $1207 \mathrm{~mA} \mathrm{~h} \mathrm{~g}^{-1}$ and $880 \mathrm{~mA} \mathrm{~h} \mathrm{~g}^{-1}$, respectively. The $\sim 27 \%$ irreversible capacity loss for the first cycle can be ascribed to the formation of the SEI layer and the decomposition of the electrolyte..$^{37}$ The electrochemical reactions during cycling can be concluded as follows:

$$
\begin{gathered}
\mathrm{Mn}_{2} \mathrm{O}_{3}+6 \mathrm{Li}^{+}+6 \mathrm{e}^{-} \rightarrow 2 \mathrm{Mn}+3 \mathrm{Li}_{2} \mathrm{O} \\
\mathrm{MnCr}_{2} \mathrm{O}_{4}+8 \mathrm{Li}^{+}+8 \mathrm{e}^{-} \rightarrow \mathrm{Mn}+2 \mathrm{Cr}+4 \mathrm{Li}_{2} \mathrm{O} \\
2 \mathrm{Cr}+3 \mathrm{Li}_{2} \mathrm{O} \leftrightarrow \mathrm{Cr}_{2} \mathrm{O}_{3}+6 \mathrm{Li}^{+}+6 \mathrm{e}^{-} \\
\mathrm{Mn}+\mathrm{Li}_{2} \mathrm{O} \leftrightarrow \mathrm{MnO}+2 \mathrm{Li}^{+}+2 \mathrm{e}^{-}
\end{gathered}
$$

It is worth pointing out that the reversed conversion (oxidation) potential of metal $\mathrm{Mn}$ to $\mathrm{MnO}\left(1.3 \mathrm{~V}\right.$ ) during $\mathrm{Li}^{+}$extraction process is higher than the conversion oxidation potential of metal $\mathrm{Cr}$ to $\mathrm{Cr}_{2} \mathrm{O}_{3}(1.27 \mathrm{~V}){ }^{56,58}$ In other words, the formed welldispersed $\mathrm{Mn}$ nanoparticles in $\mathrm{Cr} / \mathrm{Li}_{2} \mathrm{O}$ matrices after full lithiation of the $\mathrm{Mn}_{2} \mathrm{O}_{3} / \mathrm{MnCr}_{2} \mathrm{O}_{4}$ can work as anchors to effectively prohibit the diffusion and coarsening of $\mathrm{Cr}$ nanocrystals during the reversed conversion reactions of $\mathrm{Cr}$, giving rise to the obviously enhanced cycling efficiency and stability. 
(a)

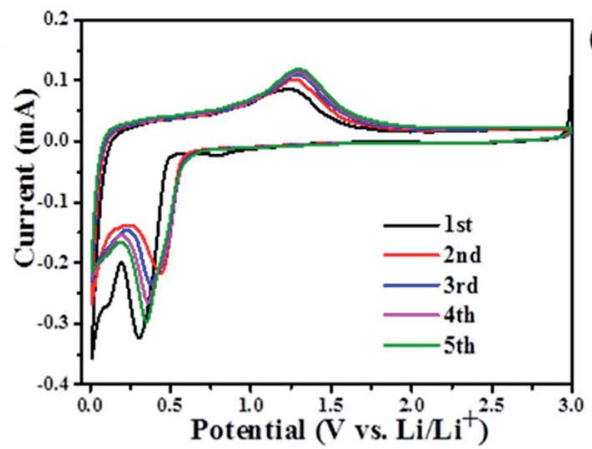

(c)

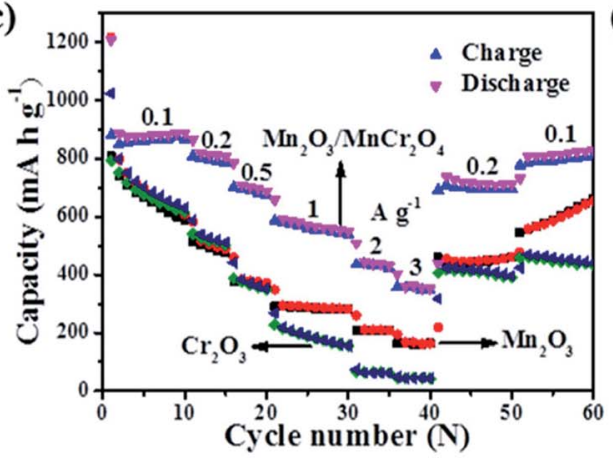

(b)

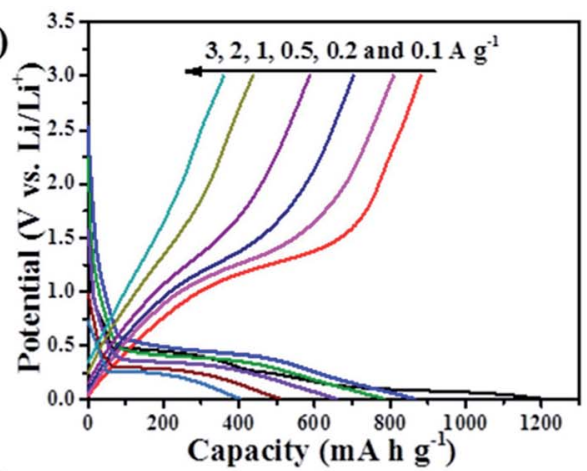

(d)

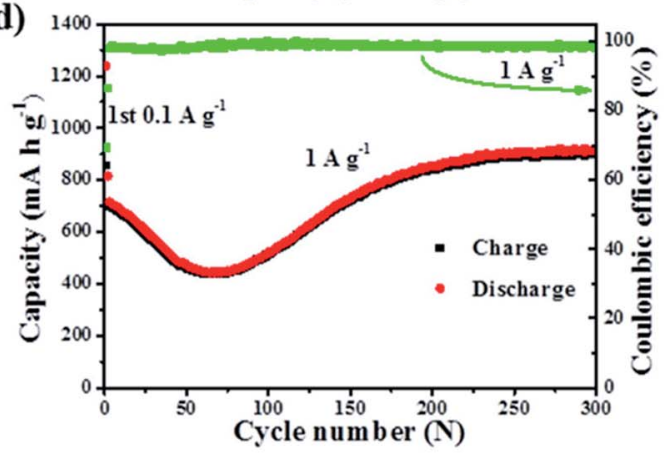

Fig. 5 (a) Cyclic voltammetry curves of the $\mathrm{Mn}_{2} \mathrm{O}_{3} / \mathrm{MnCr}_{2} \mathrm{O}_{4}$ electrode at a scan rate of $0.1 \mathrm{mV} \mathrm{s}^{-1}$ with the potential ranging from 0.01 to $3 \mathrm{~V}$ for the initial five cycles; (b) discharge and charge profiles at the current densities ranging from 0.1 to $3 \mathrm{~A} \mathrm{~g}^{-1}$ for the $\mathrm{Mn}_{2} \mathrm{O}_{3} / \mathrm{MnCr}_{2} \mathrm{O}_{4}$ electrode; (c) rate performance of the $\mathrm{Mn}_{2} \mathrm{O}_{3}, \mathrm{Mn}_{2} \mathrm{O}_{3} / \mathrm{MnCr}_{2} \mathrm{O}_{4}$ and $\mathrm{Cr}_{2} \mathrm{O}_{3}$ electrode at different current densities; (d) cycling performance and coulombic efficiency of the $\mathrm{Mn}_{2} \mathrm{O}_{3} / \mathrm{MnCr}_{2} \mathrm{O}_{4}$ electrode at $1 \mathrm{~A} \mathrm{~g}^{-1}$.

The upgrade of electrochemical properties is also reflected in rate performances, and the comparison between the $\mathrm{Mn}_{2} \mathrm{O}_{3}$, $\mathrm{Mn}_{2} \mathrm{O}_{3} / \mathrm{MnCr}_{2} \mathrm{O}_{4}$ and $\mathrm{Cr}_{2} \mathrm{O}_{3}$ electrodes were evaluated in the range from 0.1 to $3 \mathrm{~A} \mathrm{~g}^{-1}$ (Fig. 5c). For the $\mathrm{Mn}_{2} \mathrm{O}_{3} / \mathrm{MnCr}_{2} \mathrm{O}_{4}$ electrode, the average reversible discharge capacities of $\sim 861$, $734,712,577,451$ and $366 \mathrm{~mA} \mathrm{~h} \mathrm{~g}^{-1}$ are obtained at 0.1, 0.2, 0.5, 1,2 and $3 \mathrm{~A} \mathrm{~g}^{-1}$, respectively. Obviously, the capacity gradually falls off as the current density increases but still remains relatively high. When the current density is reduced back to $0.2 \mathrm{~A} \mathrm{~g}^{-1}$, the charge capacity also recovers to $693 \mathrm{~mA} \mathrm{~h} \mathrm{~g}^{-1}$, indicating the high stability as well as excellent reversibility of the electrode. The rate performance of the $\mathrm{Mn}_{2} \mathrm{O}_{3} / \mathrm{MnCr}_{2} \mathrm{O}_{4}$ electrode is obviously much better than those of $\mathrm{Mn}_{2} \mathrm{O}_{3}$ and $\mathrm{Cr}_{2} \mathrm{O}_{3}$ electrodes. The excellent rate capability may be benefited from the presence of the interconnected nanosheets and porous structure, as well as the grain boundaries for elevating the transportation of both $\mathrm{Li}^{+}$and electrons. ${ }^{10}$

To understand the capacity and stability of the $\mathrm{Mn}_{2} \mathrm{O}_{3}$, $\mathrm{Mn}_{2} \mathrm{O}_{3} / \mathrm{MnCr}_{2} \mathrm{O}_{4}$ and $\mathrm{Cr}_{2} \mathrm{O}_{3}$ electrodes, the cycling stability test was carried out at a current density of $1 \mathrm{~A} \mathrm{~g}^{-1}$ for 200 cycles (ESI, Fig. S6 $\dagger$ ). The initial Coulombic efficiency of the $\mathrm{Mn}_{2} \mathrm{O}_{3}, \mathrm{Mn}_{2} \mathrm{O}_{3} /$ $\mathrm{MnCr}_{2} \mathrm{O}_{4}$ and $\mathrm{Cr}_{2} \mathrm{O}_{3}$ electrodes are $55.4 \%, 72.9 \%$ and $79.2 \%$, respectively. In the first cycle, a large irreversible capacity can be observed because of the formation of the SEI composite. ${ }^{37}$ The discharge capacities of the $\mathrm{Mn}_{2} \mathrm{O}_{3}, \mathrm{Mn}_{2} \mathrm{O}_{3} / \mathrm{MnCr}_{2} \mathrm{O}_{4}$ and $\mathrm{Cr}_{2} \mathrm{O}_{3}$ electrodes are 400,854 and $113 \mathrm{~mA} \mathrm{~h} \mathrm{~g}^{-1}$ in the 200th cycle, respectively. The discharge capacity retention rate of the $\mathrm{Mn}_{2} \mathrm{O}_{3}$, $\mathrm{Mn}_{2} \mathrm{O}_{3} / \mathrm{MnCr}_{2} \mathrm{O}_{4}$ and $\mathrm{Cr}_{2} \mathrm{O}_{3}$ electrodes are $74.5 \%, 104.8 \%$ and
$38.3 \%$ compared with the 2nd cycle, respectively. The discharge capacity of the $\mathrm{Mn}_{2} \mathrm{O}_{3}$ decreases to $242 \mathrm{~mA} \mathrm{~h} \mathrm{~g}^{-1}$ in the 66th cycle, then increases to $429 \mathrm{~mA} \mathrm{~h} \mathrm{~g}^{-1}$ in the 157 th cycle, after that, the capacity decreases slowly. The discharge capacity of the $\mathrm{Mn}_{2} \mathrm{O}_{3} / \mathrm{MnCr}_{2} \mathrm{O}_{4}$ electrode shows an obvious capacity fading to $442 \mathrm{~mA} \mathrm{~h} \mathrm{~g}^{-1}$ in the 64th cycle, then increases continuously to $854 \mathrm{~mA} \mathrm{~h} \mathrm{~g}^{-1}$ in the 200th cycle. The discharge capacity of the $\mathrm{Cr}_{2} \mathrm{O}_{3}$ electrode falls down rapidly to $164 \mathrm{~mA} \mathrm{~h} \mathrm{~g}{ }^{-1}$ in the 10th cycle, then decreases slowly. The phenomenon may be ascribed to the comprehensive effects of the continuous formation of the SEI film on the new active surfaces caused by the repetitive volume change during the discharge/charge cycles. ${ }^{59}$ The lithiation induced reactivation of the $\mathrm{Mn}_{2} \mathrm{O}_{3}$ and $\mathrm{Mn}_{2} \mathrm{O}_{3} / \mathrm{MnCr}_{2} \mathrm{O}_{4}$ electrodes is a similar phenomenon observed in transition metal oxide electrodes. ${ }^{7,8}$ The excellent stability of the $\mathrm{Mn}_{2} \mathrm{O}_{3} /$ $\mathrm{MnCr}_{2} \mathrm{O}_{4}$ electrode also can be ascribed to the special structure of the nanosheets and porous structure, which can effectively buffer volume expansion and prevent the aggregation during the conversion processes of the formation and decomposition of $\mathrm{Li}_{2} \mathrm{O}$, accompanying the reduction and oxidation of metal nanoparticles. ${ }^{10,11,44}$

The cycling performances of the $\mathrm{Mn}_{2} \mathrm{O}_{3} / \mathrm{MnCr}_{2} \mathrm{O}_{4}$ electrode at the current densities of $0.1,0.5$ and $1 \mathrm{~A} \mathrm{~g}^{-1}$ show in Fig. $5 \mathrm{~d}$ and Fig. S7 (ESI). $\dagger$ Under different current densities, the discharge capacities show the same tendency, gradually decreases first, then increases, it obtains $913 \mathrm{~mA} \mathrm{~h} \mathrm{~g}^{-1}$ at $1 \mathrm{~A} \mathrm{~g}^{-1}$ in the 300 th cycle, more than $200 \%$ capacity recovery from the lowest value at the same rate. The drastic capacity fading is 
caused by the lithiation-induced mechanical degradation and the formation of unstable SEI. ${ }^{60}$ The gradually increasing capacity can be reasonably explained by the electrochemical activation of active materials and electrochemical catalysis of $\mathrm{Li}_{2} \mathrm{O}$ and metal grains, which is a common phenomenon observed in other TMOs. ${ }^{61}$ The coulombic efficiency increases to $98 \%$ after three initial cycles, and then remains over this level until 400 cycles are completed. High coulombic efficiency indicates that a stable SEI layer formed during the initial cycles. With the formation of a stable SEI layer, the structure-refined electrode exhibits a higher reversible specific capacity. The $\mathrm{Mn}_{2} \mathrm{O}_{3} / \mathrm{MnCr}_{2} \mathrm{O}_{4}$ electrode also exhibits a long cycling performance at a high current density of $3 \mathrm{~A} \mathrm{~g}^{-1}$ for 1000 cycles (ESI, Fig. S8 $\dagger$ ). The discharge capacity gradually decreases to $208 \mathrm{~mA} \mathrm{~h} \mathrm{~g}^{-1}$ in the 159 th cycle, then increases to $380 \mathrm{~mA} \mathrm{~h} \mathrm{~g}^{-1}$ in the 322 th cycle, and it still obtains $320 \mathrm{~mA} \mathrm{~h} \mathrm{~g}^{-1}$ in the 1000th cycle.

To further reveal the differences of transport kinetics, the electrochemical impedance spectra (EIS) of all materials were analyzed. Fig. 6 displays the Nyquist plots of the $\mathrm{Mn}_{2} \mathrm{O}_{3}, \mathrm{Mn}_{2} \mathrm{O}_{3} /$ $\mathrm{MnCr}_{2} \mathrm{O}_{4}$ and $\mathrm{Cr}_{2} \mathrm{O}_{3}$ electrodes. As observed in the Nyquist plots, all the three samples show a compressed semicircle in the high frequency region and an inclined line in the low-frequency region, which can be assigned to the charge-transfer resistance and semidiffusion of $\mathrm{Li}^{+}$respectively. ${ }^{18}$ It can be clearly observed that the $\mathrm{Mn}_{2} \mathrm{O}_{3}$ nanocomposite electrode shows the lowest charge transfer resistance, and $\mathrm{Mn}_{2} \mathrm{O}_{3} / \mathrm{MnCr}_{2} \mathrm{O}_{4}$ electrode has a significantly lower charge transfer resistance than the $\mathrm{Cr}_{2} \mathrm{O}_{3}$ electrode, suggesting that increase the content of $\mathrm{Mn}_{2} \mathrm{O}_{3}$ can improve the electrical conductivity of $\mathrm{Mn}_{2} \mathrm{O}_{3} / \mathrm{MnCr}_{2} \mathrm{O}_{4}$ electrode. So the $\mathrm{Mn}_{2} \mathrm{O}_{3} / \mathrm{MnCr}_{2} \mathrm{O}_{4}$ electrode obtained more transport channels for electrons and $\mathrm{Li}^{+}$. Herein, not only can be the particular structure of the $\mathrm{Mn}_{2} \mathrm{O}_{3} / \mathrm{MnCr}_{2} \mathrm{O}_{4}$ nanosheets mitigates the aggregation and contact resistance, but it also can provide a short way for electrons and ions to transfer, which is in favor of its outstanding electrochemical performance.

Surface SEM images of the $\mathrm{Mn}_{2} \mathrm{O}_{3} / \mathrm{MnCr}_{2} \mathrm{O}_{4}$ electrode at 0th and 1000th cycles were measured to confirm the influence of nanosheets structure on the integrity of electrodes after cycling (Fig. 7). Surface of the $\mathrm{Mn}_{2} \mathrm{O}_{3} / \mathrm{MnCr}_{2} \mathrm{O}_{4}$ electrode before cycling has uniform mixed active materials and conductive agents with

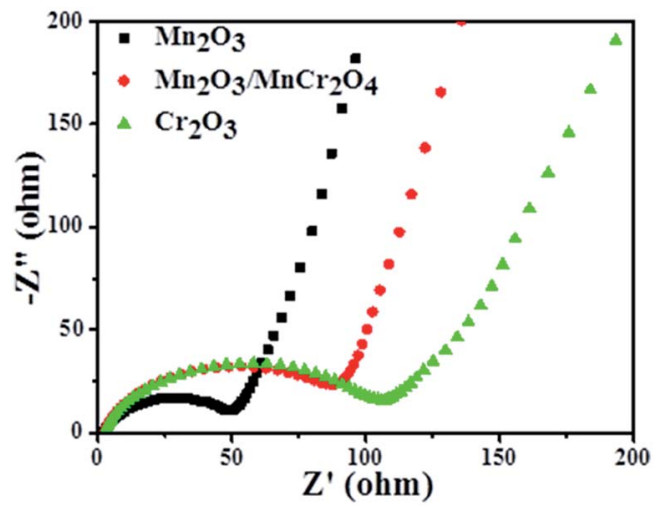

Fig. 6 Nyquist plots for the $\mathrm{Mn}_{2} \mathrm{O}_{3}, \mathrm{Mn}_{2} \mathrm{O}_{3} / \mathrm{MnCr}_{2} \mathrm{O}_{4}$ and $\mathrm{Cr}_{2} \mathrm{O}_{3}$ electrodes.

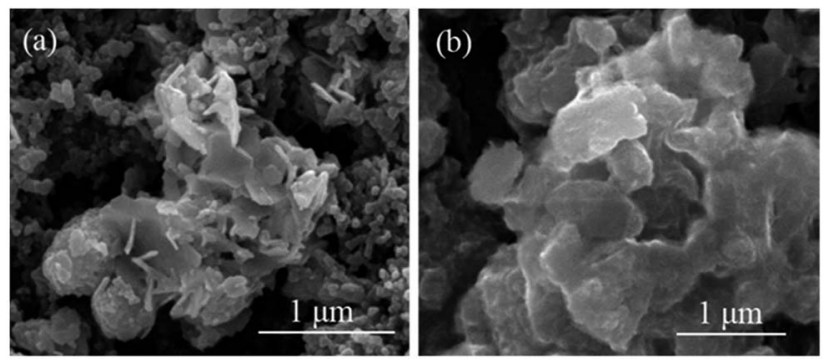

Fig. 7 SEM images of the electrode for the $\mathrm{Mn}_{2} \mathrm{O}_{3} / \mathrm{MnCr}_{2} \mathrm{O}_{4}$ before (a) and after (b) 1000 cycles at $1 \mathrm{~A} \mathrm{~g}^{-1}$.

integrated structure (Fig. 7a). After 1000 cycles at $3 \mathrm{~A} \mathrm{~g}^{-1}$, the electrode retains its integrated shape as shows in Fig. 7b, indicating the good structural stability of the $\mathrm{Mn}_{2} \mathrm{O}_{3} / \mathrm{MnCr}_{2} \mathrm{O}_{4}$ during the process of $\mathrm{Li}^{+}$uptake/extraction. The nanosheets structure mitigates the volume changes and thus facilitates electrode stability and good electrical contact during long cycling. ${ }^{\mathbf{4 4}}$

Based on the above experimental results and analysis, we can infer that the following strategically interdependent characteristics of the $\mathrm{Mn}_{2} \mathrm{O}_{3} / \mathrm{MnCr}_{2} \mathrm{O}_{4}$ hybrid nanosheets are responsible for the outstanding LIBs performance. The nanosheets structure can effectively withstand the mechanical stress during the charge-discharge processes. Further more, the interconnected nanosheets and porous structure facilitates quick transmission channels for $\mathrm{Li}^{+}$and electrons among active materials, and can also protect the stable structure from collapse and aggregation so as to reduce the resistance. Therefore, both the poor conductivity and volume changes of the $\mathrm{Mn}_{2} \mathrm{O}_{3} / \mathrm{MnCr}_{2} \mathrm{O}_{4}$ electrode can be circumvented by the as-prepared $\mathrm{Mn}_{2} \mathrm{O}_{3} / \mathrm{MnCr}_{2} \mathrm{O}_{4}$ hybrid nanosheets, which is beneficial for directing other multiphase TMOs electrode designs.

\section{Conclusions}

In conclusion, the $\mathrm{Mn}_{2} \mathrm{O}_{3} / \mathrm{MnCr}_{2} \mathrm{O}_{4}$ hybrid nanosheets have been successfully prepared from a facile synthesis approach by thermal decomposition of the $\mathrm{Mn}-\mathrm{Cr}$ binary hydroxides and carbonate hybrid precursor. The special structure was designed simultaneously to enable the effective restriction of the volumetric expansion of the $\mathrm{Mn}_{2} \mathrm{O}_{3} / \mathrm{MnCr}_{2} \mathrm{O}_{4}$ as well as provide good electron and ion transport capability based on electrochemical impedance spectra. The electrochemical measurements demonstrate that the $\mathrm{Mn}_{2} \mathrm{O}_{3} / \mathrm{MnCr}_{2} \mathrm{O}_{4}$ electrode delivers an excellent reversible capacity of $913 \mathrm{~mA} \mathrm{~h} \mathrm{~g}^{-1}$ at a current density of $1 \mathrm{~A} \mathrm{~g}^{-1}$ after 300 cycles and excellent rate performance. The facile and scalable approach to fabricate the $\mathrm{Mn}_{2} \mathrm{O}_{3} / \mathrm{MnCr}_{2} \mathrm{O}_{4}$ hybrid nanosheets can expand the scope of the design concept of multiphase TMOs for LIBs application.

\section{Conflicts of interest}

There are no conflicts to declare. 


\section{Acknowledgements}

This work is supported by the Emerging Strategic Industrial Science and Technology Project of Hunan province, China (2016GK4020), the National Natural Science Foundation of China (No. 51404041), and the Natural Science Foundation of Hunan province, China (No. 2018JJ2513).

\section{References}

1 C. P. Grey and J. M. Tarascon, Nat. Mater., 2016, 16, 45-56. 2 S. Chu, Y. Cui and N. Liu, Nat. Mater., 2016, 16, 16-22.

3 C. Zhang, Nat. Energy, 2017, 2, 17099.

4 D. Vincent and L. Martiradonna, Nat. Mater., 2016, 16, 15.

5 Q. Liu, C. Du, B. Shen, P. Zuo, X. Cheng, Y. Ma, G. Yin and Y. Gao, $R S C$ Adv., 2016, 6, 88683-88700.

6 K. G. Gallagher, S. E. Trask, C. Bauer, T. Woehrle, S. F. Lux, M. Tschech, P. Lamp, B. J. Polzin, S. Ha, B. Long, B. Long, Q. Wu, W. Lu, D. W. Dees and A. N. Jansena, J. Electrochem. Soc., 2016, 163, A138-A149.

7 Y. Wang, J. Roller and R. Maric, J. Power Sources, 2018, 378, 511-515.

8 G. Zhao, X. Sun, L. Zhang, X. Chen, Y. Mao and K. Sun, J. Power Sources, 2018, 389, 8-12.

9 P. Poizot, S. Laruelle, S. Grugeon, L. Dupont and J. M. Tarascon, Nature, 2000, 407, 496-499.

10 S. Zhu, J. Li, X. Deng, C. He, E. Liu, F. He, C. Shi and N. Zhao, Adv. Funct. Mater., 2017, 27, 1605017.

11 Z. Cao, M. Qin, B. Jia, L. Zhang, Q. Wan, M. Wang, A. A. Volinsky and X. Qu, Electrochim. Acta, 2014, 139, 76-81.

12 Z. Bai, Y. Zhang, Y. Zhang, C. Guo, B. Tang and D. Sun, J. Mater. Chem. A, 2015, 3, 5266-5269.

13 G. Zhang and X. W. Lou, Angew. Chem., Int. Ed., 2014, 126, 9187-9190.

14 N. Wang, J. Yue, L. Chen, Y. Qian and J. Yang, ACS Appl. Mater. Interfaces, 2015, 7, 10348-10355.

15 X. Liu, C. Zhao, H. Zhang and Q. Shen, Electrochim. Acta, 2015, 151, 56-62.

16 Y. Xiang, H. Wu, K. H. L. Zhang, M. Coto, T. Zhao, S. Chen, B. Dong, S. Lu, A. Abdelkader, Y. Guo, Y. Zhang, S. Ding, K. Xi and G. Gao, J. Mater. Chem. A, 2017, 5, 8062-8069.

17 S. Yuan, Y. Zhao, W. Chen, C. Wu, X. Wang, L. Zhang and W. Qiang, ACS Appl. Mater. Interfaces, 2017, 9, 21781-21790.

18 H. Kong, C. Lv, C. Yan and G. Chen, Inorg. Chem., 2017, 56, 7642-7649.

19 A. A. Abdelhamid, Y. Yu, J. Yang and J. Y. Ying, Adv. Mater., 2017, 29, 1701427.

20 Y. Yuan, C. Zhan, K. He, H. Chen, W. Yao, S. Sharifiasl, B. Song, Z. Yang, A. Nie, X. Luo, H. Wang, S. M. Wood, K. Amine, M. S. Islam, J. Lu and R. Shahbazian-Yassar, Nat. Commun., 2016, 7, 13374.

21 T. L. Nguyen, D. S. Kim, J. Hur, M. S. Park, S. Yoon and I. T. Kim, J. Power Sources, 2018, 389, 28-36.

22 H. Tan, H. W. Cho and J. J. Wu, J. Power Sources, 2018, 388, 11-18.

23 Z. Wang, Y. Cheng, Q. Li, L. Chang and L. Wang, J. Power Sources, 2018, 389, 214-221.
24 P. Zheng, Y. Zhang, Z. Dai, Y. Zheng, K. N. Dinh, J. Yang, R. Dangol, X. Liu and Q. Yan, Small, 2018, 14, 1704065.

25 S. Lu, T. Zhu, Z. Li, Y. Pang, L. Shi, S. Ding and G. Gao, J. Mater. Chem. A, 2018, 6, 7005-7013.

26 G. Gao, Y. Xiang, S. Lu, B. Dong, S. Chen, L. Shi, Y. Wang, H. Wu, Z. Li, A. Abdelkader, K. Xi and S. Ding, Nanoscale, 2018, 10, 921-929.

27 G. Gao, S. Lu, B. Dong, W. Yan, W. Wang, T. Zhao, C. Y. Lao, K. Xi, R. V. Kumar and S. Ding, J. Mater. Chem. A, 2016, 4, 10419-10424.

28 G. Gao, S. Lu, Y. Xiang, B. Dong, W. Yan and S. Ding, Dalton Trans., 2015, 44, 18737-18742.

29 J. Xu, H. Zhang, R. Wang, P. Xu, Y. Tong, Q. Lu and F. Gao, Langmuir, 2018, 34, 1242-1248.

30 Y. Chen, Y. Wang, X. Shen, R. Cai, H. Yang, K. Xu, A. Yuan and Z. Ji, J. Mater. Chem. A, 2017, 6, 1048-1056.

31 Y. Lu, J. Nai and X. W. Lou, Angew. Chem., Int. Ed., 2018, 57, 2899-2903.

32 W. Wang, N. Wu, J. M. Zhou, F. Li, Y. Wei, T. H. Li and X. L. Wu, Nanoscale, 2018, 10, 6832-6836.

33 L. Lu, Y. L. Gao, Z. Z. Yang, C. Wang, J. G. Wang, H. Y. Wang and Q. C. Jiang, J. Power Sources, 2018, 384, 256-263.

34 H. Liu, Q. Li, Z. Yao, L. Li, Y. Li, C. Wolverton, M. C. Hersam, J. Wu and V. P. Dravid, Adv. Mater., 2017, 30, 1704851.

35 X. Lin, K. Wu, L. Shao, M. Shui, X. Jiang, D. Wang, N. Long, Y. Ren and J. Shu, J. Alloys Compd., 2014, 598, 68-72.

36 J. Zhou, S. Cheng, Y. Jiang, F. Zheng, X. Ou, L. Yang, M. Wang, M. Yao and M. Liu, $R S C A d v ., 2017,7,21214-$ 21220.

37 H. B. Lin, H. B. Rong, W. Z. Huang, Y. H. Liao, L. D. Xing, M. Q. Xu, X. P. Li and W. S. Li, J. Mater. Chem. A, 2014, 2, 14189-14194.

38 Y. Zhang, Y. Yan, X. Wang, G. Li, D. Deng, L. Jiang, C. Shu and C. Wang, Chem.-Eur. J., 2014, 20, 6126-6130.

39 X. Li, D. Li, L. Qiao, X. Wang, X. Sun, P. Wang and D. He, J. Mater. Chem., 2012, 22, 9189-9194.

40 J. Yue, X. Gu, L. Chen, N. Wang, X. Jiang, H. Xu, J. Yang and Y. Qian, J. Mater. Chem. A, 2014, 2, 17421-17426.

41 S. Khalid, C. Cao, M. Naveed and W. Younas, Sustainable Energy Fuels, 2017, 1, 1795-1804.

42 Y. Deng, Z. Li, Z. Shi, H. Xu, F. Peng and G. Chen, RSC Adv., 2012, 2, 4645-4647.

43 Y. Dai, H. Jiang, Y. Hu and C. Li, RSC Adv., 2013, 3, 1977819781.

44 C. Zhao, H. Zhang, W. Si and H. Wu, Nat. Commun., 2016, 7, 12543.

45 J. Sun, K. Tang, X. Yu, J. Hu, H. Li and X. Huang, Solid State Ionics, 2008, 179, 2390-2395.

46 L. Dupont, S. Laruelle, S. Grugeon, C. Dickinson, W. Zhou and J. M. Tarascon, J. Power Sources, 2008, 175, 502-509.

47 J. Hu, H. Li, X. Huang and L. Chen, Solid State Ionics, 2006, 177, 2791-2799.

48 Y. Chen, Z. Liu, S. P. Ringer, Z. Tong, X. Cui and Y. Chen, Cryst. Growth Des., 2007, 7, 2279-2281.

49 D. Lenaz, H. Skogby, F. Princivalle and U. Hålenius, Phys. Chem. Miner., 2004, 31, 633-642. 
50 R. N. Bhowmik and R. Ranganathan, Phys. Rev. B: Condens. Matter Mater. Phys., 2006, 73, 144413.

51 Y. Wang, W. Lai, N. Wang, Z. Jiang, X. Wang, P. Zou, Z. Lin, H. J. Fan, F. Kang, C. P. Wong and C. Yang, Energy Environ. Sci., 2017, 10, 941-949.

$52 \mathrm{~J} . \mathrm{Hu}, \mathrm{H} . \mathrm{Li}$ and X. J. Huang, Electrochem. Solid-State Lett., 2005, 8, A66-A69.

53 Q. Zhang, J. Wang, J. Dong, F. Ding, X. Li, B. Zhang, S. Yang and K. Zhang, Nano Energy, 2015, 13, 77-91.

54 S. Zhu, J. Li, C. He, N. Zhao, E. Liu, C. Shi and M. Zhang, J. Mater. Chem. A, 2015, 3, 22266-22273.

55 C. Zhu, R. E. Usiskin, Y. Yu and J. Maier, Science, 2017, 358, 1400.

56 F. Wang, W. Li, M. Hou, C. Li, Y. Wang and Y. Xia, J. Mater. Chem. A, 2014, 3, 1703-1708.
57 W. Zhang, J. Li, J. Zhang, J. Sheng, T. He, M. Tian, Y. Zhao, C. Xie, L. Mai and S. Mu, ACS Appl. Mater. Interfaces, 2017, 9, 12680-12686.

58 J. T. Li, V. Maurice, J. Swiatowska-Mrowiecka, A. Seyeux, S. Zanna, L. Klein, S. G. Sun and P. Marcus, Electrochim. Acta, 2009, 54, 3700-3707.

59 Y. Zeng, L. F. Li, H. Li, X. J. Huang and L. Q. Chen, Ionics, 2009, 15, 91-96.

60 H. Sun, G. Xin, T. Hu, M. Yu, D. Shao, X. Sun and J. Lian, Nat. Commun., 2014, 5, 4526.

61 Y. Y. Hu, Z. Liu, K. W. Nam, O. J. Borkiewicz, J. Cheng, X. Hua, M. T. Dunstan, X. Yu, K. M. Wiaderek, L. S. Du, K. W. Chapman, P. J. Chupas, X. Q. Yang and C. P. Grey, Nat. Mater., 2013, 12, 1130-1136. 